\title{
RODOWODY ŻYDOWSKIE W LITERACKIEJ INTERPRETACJI FRIDRICHA GORENSZTEJNA. BERDYCZÓW
}

\author{
Magdalena SZMORĄG-NERĆ (Uniwersytet Szczeciński)
}

Żydowsko-rosyjski literat Fridrich Gorensztejn (1932-2002), określany mianem drugiego Dostojewskiego ${ }^{1}$, swój etniczny i kulturowy rodowód wywodzi z dawnego sztetla - Berdyczowa. To w tym miasteczku, ukształtowanym przez wielowiekową historię wspólnoty żydowskiej, przyszły prozaik, dramaturg i scenarzysta wychowywany był, po tragicznej śmierci obojga rodziców, przez ciotki. Pewnie dlatego swoje pojmowanie żydowskości ukonstytuował twórca na zanikłej w czasach radzieckich żydowskiej cywilizacji strefy osiedlenia ${ }^{2}$, na którą składały się zubożałe społeczności, wyludnione miasteczka oraz oszpecony, zsowietyzowany język jidysz ${ }^{3}$, a nie w oparciu o judaizm czy lewicowe idee syjonistyczne. Taki jej obraz przedstawił w sztuce Ber$d y c z o ́ w^{4}$. Powstała ona, stwierdza autor, pod wpływem samego Berdyczowa ${ }^{5}$. Zdaniem krytyków, stanowi niepowtarzalny hymn na cześć sztetla i uważana jest za jeden

${ }^{1}$ Г. Никифорович, Фридрих Горенштейн: писатель и читатели, Иерусалимский журнал $2012 \mathrm{nr}$ 41, http://magazines.russ.ru/ier/2012/41/g20-pr.html (dostęp: styczeń 2015).

${ }^{2}$ Strefa osiedlenia to wyznaczony w 1791 r. przez carycę Katarzynę II obszar w zachodniej części imperium rosyjskiego, który zamieszkiwali Żydzi. Nie wolno im było go opuszczać bez specjalnego zezwolenia. Strefę osiedlenia zlikwidowano w $1917 \mathrm{r}$.

${ }_{3}^{3}$ Ш. Маркиш, Плач о мастере, Вести 2008, http://www.sem40.ru/famous2/m1539.shtml (dostęp: październik 2014).

${ }^{4}$ Sztuka Berdyczów z podtytułem Dramat w trzech aktach, ośmiu odsłonach, 92 skandalach (Бердичев. Драма в трех действиях, восьми картинах, 92 скандалах) została ukończona w 1975 r. Pierwsza publikacja miała miejsce w Tel Awiwie w czasopiśmie „Время и мы” (1980). W Rosji ukazała się w wydawnictwie Slovo/Word (1988). Wartości literackie sztuki podnosiło wielu komentatorów krytyczno-literackich (Mina Poljanska, Jurij Weksler, Jevgenij Kudrjac, Elina Wasiliewa). W lutym 2014 r. sztukę wystawiono na scenie Teatru Moskiewskiego imienia Majakowskiego w reżyserii Nikity Kobeliova.

${ }^{5}$ Ф. Горенштейн, Как я был шпионом ЦРУ?, Зеркало Загадок $2000 \mathrm{nr}$ 9, s. 33. 
z najlepszych utworów pisarza ${ }^{6}$. Berdyczów, słusznie zauważa Jurij Weksler, to epopeja ujęta w ramy gatunkowe dramatu ${ }^{7}$, sięgająca do tradycji powieści z początku XX wie$\mathrm{ku}$, przede wszystkim do epopei rodzinnej. ${ }^{8}$. W sztuce przedstawiono historię rodu Łuckich na przestrzeni ponad trzech dekad. Dzieje rodziny są tutaj metaforą historii narodu żydowskiego, a kryzys, jakiego doświadczają Łuccy, stanowi bezpośrednie odniesienie do przeobrażeń kulturowych i historycznych całej nacji ${ }^{9}$.

Sztuka składa się z trzech aktów i ośmiu scen. Akcja każdej z nich toczy się $\mathrm{w}$ ciągu jednego dnia innego roku ${ }^{10}$. Ustalenie daty jest problematyczne, bowiem w didaskaliach podano konkretny czas akcji tylko dwóch pierwszych scen, w pozostałych ustala się go na podstawie wypowiedzi i wspomnień postaci lub omawianych wydarzeń społeczno-politycznych.

Akcja rozpoczyna się latem 1945 r., po powrocie z ewakuacji do bezpiecznego już, wyzwolonego po okupacji faszystowskiej Berdyczowa. Linia fabularna koncentruje się wokół sióstr Łuckich oraz osób z ich najbliższego otoczenia, tworzących swoisty model berdyczowskiego świata ${ }^{11}$. Centralną postacią jest Rachela Abramowna Łuckaja, po mężu Kapcan, wdowa, matka dwóch nastoletnich córek - Rózi i Lusi. Wraz z nią mieszka starsza siostra Złota Łuckaja oraz osierocony siostrzeniec - Wilja. Do najbliższego kręgu rodziny należy mieszkający w Berdyczowie ich starszy brat, Sumier Abramowicz. Druga wojna światowa odcisnęła swe tragiczne piętno na rodzinie sióstr Łuckich: zginął młodszy brat - Szlojma, zmarła siostra, Rachela straciła męża, a Sumier jedynego syna. Postaci Racheli i Złoty wydają się mieć swoje autentyczne prototypy ciotki autora. W sztuce noszą one prawdziwe imiona oraz patronimikum, a nazwisko Łuckaja jest zbliżone do nazwiska panieńskiego matki pisarza — Priłuckaja.

Więź Łuckich z tradycyjnym życiem małomiasteczkowych Żydów jest zróżnicowana. Najstarszy z nich, Sumier, urodzony w ostatnim dziesięcioleciu XIX wieku, najpełniej poznał życie sztetla, a najmłodsza Rachela, urodzona w roku 1905, najmniej $^{12}$. Pewnie dlatego jej tożsamość jest radziecko-żydowska, hybrydowa, z przewagą komponentu sowieckiego. Jest Żydówką, ale niewierzącą, bowiem przy intensywnych antyreligijnych działaniach państwa, laicyzacji oraz ateizacji, niemożliwe było, jak również niebezpieczne, sprawowanie kultu religijnego. Nie jest związana z żadnymi żydowskimi ruchami narodowymi, nie akceptuje państwa Izrael i nie pochwala emigracji doń. Uważa siebie za obywatelkę państwa radzieckiego, co najdobitniej wyraża, po pierwsze, często podkreślane wspomnienie o mężu, który zginął w obronie kraju („Мой муж убит на фронт”), а — po drugie — jej wieloletnie członkostwo w partii komunistycznej (,Я член партии с 28-го года”). W ten sposób bohaterka podkreśla i udowadnia rozmówcom wagę należnego jej miejsca $\mathrm{w}$ państwie radziec-

\footnotetext{
${ }^{6}$ М. Полянская, Берлинские записки о Фридрихе Горенштейне, Санкт-Петербург 2011, s. 37,166 .

${ }^{7}$ Ю. Векслер, ,Меня будут признавать сквозь зубы”, http://www.svoboda.org/content/ transcript/24350362.html (dostęp: lipiec 2013).

8 Э. Васильева, Художественный мир драмы Фридриха Горенштейна „Бердичев”, Семь искусств $2014 \mathrm{nr}$ 1, http://7iskusstv.com/2014/Nomer1/Vasiljeva1.php (dostęp: październik 2014).

${ }^{9}$ Tamże.

${ }^{10}$ Scena pierwsza i druga: 1945 r., trzecia: 1946 r., czwarta: 1947 r., piąta: 1956 r., szósta: 1969 r., siódma: 1970 r., ósma — prawdopodobnie — 1974 r.

${ }^{11}$ Tamże.

${ }^{12} \mathrm{Na}$ podstawie zawartych w tekście informacji (dat i wydarzeń) można przypuszczać, że Rachela urodziła się w roku 1905, Złota — 1898, a Sumier — między 1890 a 1894.
} 
kim. 9 maja 1969 r., podczas uroczystości z okazji Dnia Zwycięstwa, ów status zostaje podważony. Pułkownik Mamatiuk, bohater i uczestnik walk o wyzwolenie Berdyczowa, stwierdza, że we wspólnej, chwalebnej mogile pochowane są wszystkie nacje, oprócz Żydów. W ten sposób, w opinii Racheli, wyklucza jej męża, a tym samym i ją, ze społeczności radzieckiej. Charakter bohaterki nie pozwala na bierne zaakceptowanie tej uwagi, dlatego, nie zważając na obecność innych uczestników uroczystości, wywołuje skandal:

РАХИЛЬ: Нет, ты слышала, что он сказал, этот гой? Чтоб его гром убил и второго тоже вместе с их женами и детьми ${ }^{13}$.

Do wydarzenia dochodzi przy obelisku na bulwarze w centrum miasta, miejscu odgrywającym istotną rolę $\mathrm{w}$ przestrzeni publicznej ${ }^{14}$ Berdyczowa. $\mathrm{Z}$ jednej strony upamiętnia ono ofiary wojny $z$ faszyzmem i stanowi świadectwo składanego im hołdu. $\mathrm{Z}$ drugiej - wpisane jest w radziecką przestrzeń kulturową, która współtworzyła nowego człowieka radzieckiego i służyła utrwalaniu tożsamości państwowej. Władza, łącząc oba znaczenia, wykorzystywała je do kultywowania, przypominania społeczeństwu o ważnych według niej wydarzeniach historycznych. Wartość sentymentalna była narzędziem manipulacji w rękach partii. Rachela czuje się podwójnie dotknięta. Swoim stwierdzeniem Mamatiuk odmawia Żydom, jako równoprawnym obywatelom, poszanowania za udział w wojnie $\mathrm{z}$ hitlerowskim faszyzmem. Straciło wówczas życie wiele osób z rodziny Łuckich, które on wyklucza ze wspólnoty ludzi radzieckich. Przekonanie Mamatiuka może wynikać $\mathrm{z}$ antysemityzmu $\mathrm{z}$ okresu drugiej wojny światowej, który podsycany przez hitlerowców, został następnie przejęty przez wyzwolicieli ${ }^{15}$.

Światopogląd i tożsamość Racheli zostały ukształtowane pod wpływem ideologii bolszewickiej, ukierunkowanej na stworzenie „,nowego człowieka”, oddanego sprawom kraju komunisty. Formowano go poprzez uczestnictwo w mityngach, agitacje i nieustannie wpajane hasła partyjne. Andriej Siniawski wyszczególnia cechy nowego człowieka-komunisty, do których należą, między innymi, bezgraniczne oddanie wyższemu celowi i wiara w idee komunizmu. Homo sovieticus to działacz i praktyk, który zmienia świat, to przedstawiciel masy lub klasy, ale zawsze zjednoczony z kolektywem. Stąd tak silny i bolesny emocjonalnie sprzeciw Racheli wobec wykluczenia i jej, i zmarłego męża z ideowej wspólnoty. Wśród cech negatywnych nowego człowieka Siniawski wskazuje egoizm ${ }^{16}$. Taka postawa wydaje się cechować Mamatiuka. Rachela — komunistka - brała udział w konferencjach partyjnych, a swoją opinię o wydarzeniach w kraju i na świecie buduje w oparciu o berdyczowską gazetę „Radjanskij szljach" i wiadomości przekazywane w telewizji. To wszystko z pewnością determino-

13 Ф. Горенштейн, Бердичев, Москва 2007, s. 127. Cytaty zostały przytoczone $\mathrm{w}$ oryginale, ponieważ tłumaczenie nie odzwierciedliłoby specyfiki zastosowanego w dramacie języka, którym posługują się postaci. W sztuce użyto niegramatycznego języka rosyjskiego ze wstawkami z języka jidysz.

${ }^{14}$ Pojęcie ,miejsca”, jak i jego znaczenia w kulturze, opracował reprezentant geografii humanistycznej, Yi-Fu Tuan (Yi-Fu Tuan, Przestrzeń i miejsce. Perspektywa doświadczania, thum. A. Morawińska, Warszawa 1987). Space and Place: Humanistic Perspective, Progress in Geography $1974 \mathrm{nr}$ 6, s. 211-252). Badacz wyróżnia miejsca należące do symboli publicznych oraz pola troski; zob. Wstęp do kulturoznawstwa, E. Baldwin [i in.], tłum. M. Kaczyński, J. Łoziński, T. Rosiński, Poznań 2007, s. 168-170.

${ }^{15}$ M. Heller, A. Niekricz, Utopia u władzy. Historia Zwiazku Sowieckiego, t. 2, thum. A. Mietkowski, Londyn 1982, s. 152.

${ }^{16}$ А. Синявский, Основы советской ичивилизации, Москва 2001, s. 159-161. 
wało działania nowego człowieka radzieckiego, a utrwalane w świadomości społecznej hasła wkraczały do jego języka potocznego. Ponadto ideologia infantylizowała obywateli, wskazując im, jak należy rozumieć wydarzenia w otaczającym świecie ${ }^{17}$.

Istotną rolę w sowietyzacji Racheli odegrał kult Stalina. Jego apoteoza jako wodza była wszechobecna w życiu społeczno-politycznym i kulturowym kraju. Na uroczystości zaślubin Rózi i Milji (1946), Rachela wraz z innymi gośćmi, takimi jak ona Żydami sowieckimi, śpiewa piosenki w jidysz na cześć Stalina i konstytucji. O tym, jak ważny w jej świadomości jest „ojciec narodów”, świadczy jego portret, który wraz z popiersiem Lenina zajmuje poczesne miejsce w jej mieszkaniu. Wizerunek wisi jeszcze jakiś czas po śmierci wodza i nie zmieniają tego nawet wydarzenia polityczne, związane z krytyką „kultu jednostki” ani odwilż. Przemiany polityczno-społeczne, z których z pewnością Rachela zdaje sobie sprawę, nie wpływają na zmianę jej poglądów, nadal pozostaje zagorzałą stalinistką i komunistką. Na jej ocenę systemu nie wpływa nawet niesłuszne aresztowanie brata — Sumiera. Warto również nadmienić, iż Szlojma Łuckij — jej brat, i mąż — Kapcan zginęli w 1942 r., kiedy operacje wojenne wojsk sowieckich prowadzone były chaotycznie, a wielu żołnierzy straciło życie z powodu niewłaściwych decyzji dowództwa. Mąż Racheli zginął pod Charkowem prawdopodobnie w toku działań Frontu Południowo-Zachodniego i Południowego. Jak pisze Michał Heller, operacja była niebezpieczna i dlatego dziesiątki tysięcy osób straciło życie ${ }^{18}$. Rachela nigdy nie skrytykowała działań, prowadzonych w czasie drugiej wojny światowej. Z pewnością nie jest nawet świadoma ich przebiegu ani tego, że jej bliscy zostali wówczas wystawieni na pewną śmierć — partia skrupulatnie to ukrywała.

W przypadku Racheli język, który służy określeniu tożsamości narodowej oraz kulturowej, udanie obrazuje proces jej sowietyzacji. Jest on dychotomiczny: mówi ona niepoprawnym gramatycznie, zniekształconym rosyjskim oraz wyuczonym w dzieciństwie jidysz. W języku rosyjskim tworzy wypowiedzi na wzór jidysz, nie odmieniając rzeczowników i naruszając składnię zdania:

РАХИЛЬ: А что, я не знаю Тайберов? Они жили до войны в нашем доме по Белопольской... Вы жили на первый этаж, я на второй этаж, а они жили над аптекой..

Они из Одесс, но перед войной приехали в Бердичев ${ }^{19}$.

Dostrzegalne jest zbiurokratyzowanie, zindoktrynowanie języka Racheli, która używa słownictwa i pojęć, jakie wprowadziło do obiegu zideologizowane, agitacyjne państwo. Posługuje się sowiecką nowomową oraz słownictwem z zakresu języka partyjno-propagandowego. Taki język narzuca sugestywny znak wartości, sens jest uzależniony od oceny, a słowa mają za zadanie tworzyć rzeczywistość, a nie ją opisywać ${ }^{20}$.

Komponent żydowski tożsamości Racheli wydaje się przejawiać w jej kłótliwości, krzykliwości czy prowokacyjnym zachowaniu. Jest osobą energiczną, silną i stanowczą. To właśnie ona niejednokrotnie jest sprawczynią i aktywną uczestniczką wskazanych w podtytule skandali. W kontaktach międzyludzkich jest bezpośrednia, otwarcie, bez ogródek wyraża swoje zdanie. Zdaniem Johna Glada została przedstawiona jako kobieta gburowata, nieprzyjemna, o „ostrym języku”, jednak wzbudzająca sympatię $^{21}$. „Koślawy” rosyjski wydaje się dominować w jej wypowiedziach. Jidysz

\footnotetext{
${ }^{17}$ M. Heller, A. Niekricz, Utopia u władzy, t. 2, s. 294.

${ }^{18}$ Tamże, t. 2, s. 66-67.

${ }^{19}$ Ф. Горенштейн, Бердичев, s. 39.

${ }^{20}$ M. Głowiński, Nowomowa po polsku, Warszawa 1990, s. 7-9.

21 Za: Ю. Векслер, „Молились и черту тоже”, Независимая газета 2012, http://www.ng.ru/ng_exlibris/2012-03-22/4_gorenstein.html (dostęp: styczeń 2014).
} 
stosuje Rachela okazjonalnie, jedynie w kręgu swoich najbliższych oraz wśród innych Żydów, osób, które go rozumieją. Jej jidysz nie zawiera haseł propagandowych, ale dostrzegalne są wpływy sowieckiej polityki kulturowej, zmierzającej do unifikacji grup etnicznych zamieszkujących obszar Związku Radzieckiego. Najtrafniej wyrażają to piosenki chwalące nowy ustrój, a wykonywane w języku etnicznym:

РАХИЛЬ: „Фар Октобер революци, ай-яй-яй-яй, ай... Фар дер Сталине конституци, ай-яй-яй-яй...,"22.

Powyższy cytat dowodzi połączenia dwóch kultur, bowiem zgodnie ze Stalinowskim sloganem treść jest tu socjalistyczna, a forma narodowa, żydowska ${ }^{23}$.

Obie siostry często używają wyrażenia żydowskiego „Ой, вэй 3 мир” ${ }^{\text {,2 }}$, które służy emocjonalnemu podkreślaniu dalszej wypowiedzi. Rachela wymawia je, gdy jest przygnębiona, smutna lub gdy wspomina osoby zmarłe. Częste użycie tego zwrotu poświadcza tkwiące w Racheli elementy kultury żydowskiej.

$\mathrm{W}$ jidysz, który jest reliktem przeszłości (w dramacie posługuje się nim tylko pokolenie sióstr), zawarta jest kultura żydowska, kultura strefy osiedlenia - dostępna właśnie poprzez ten język. Warto zaznaczyć, że język stanowi swoiste archiwum kulturowe społeczeństwa ${ }^{25}$. Stąd język Racheli jest wyrazem pamięci o tradycji żydowskiej.

Stosunek do macierzyństwa i kultywowanie wartości rodzinnych to niezaprzeczalnie szczególny przejaw składowej żydowskiej w tożsamości Racheli. Bez wątpienia to ona jest głową rodziny, pracuje, aby utrzymać siebie i córki, troszczy się o swoich bliskich, opiekuje się nimi. Najważniejszą wartością w jej życiu są dzieci. Dla nich jest zdolna zrobić wszystko. Jako dewizę, którą kieruje się w swym postępowaniu Rachela, można wskazać następujące stwierdzenie:

РАХИЛЬ: [...] Для своих детей я должна быть хорошая, а для всех остальных я не хочу быть хорошая... Пусть про меня говорят что угодно, мне кисло в заднице... ${ }^{26}$.

W tradycji żydowskiej imię Rachela odnosi się do biblijnej Rachel, pramatki, od której wywodzą się dwa pokolenia Izraela. Berdyczowska Rachela również ma dwoje dzieci - córki, które zgodnie z prawem Halachy przekazują swoim dzieciom dziedzictwo przynależności do narodu wybranego. Rachela Gorensztejna reprezentuje tę pramatkę, od której bierze początek pełna asymilacja Żydów, zamieszkujących dawny sztetl. Jej latorośle kontynuują ten proces. Córki Racheli wychowane są w systemie radzieckim. Należą do pionierów i kształcą się w szkołach państwowych. Warto przypomnieć, że w latach 20. XX wieku państwo przeprowadziło reformę szkolnictwa. Nauczanie upolityczniono i dążono do wychowania młodzieży internacjonalistycznej,

${ }^{22}$ Ф. Горенштейн, Бердичев, s. 43-44.

23 В. Шубинский, Мессианский вирус. Фридрих Горенштейн, Россия и еврейство: попьттка введения в тему, http://www.narodknigi.ru/journals/38/messianskiy_virus/ (dostęp: maj 2013).

${ }^{24}$ „Вей $з$ мир” oznacza mniej więcej „biada mi!” lub „Boże mój!”. Wyraża zdziwienie, współczucie i strach. Za: М. Чабан, Идиш в Одессе - 4. Ой, не надо мне сказать!, Заметки по еврейской истории $2011 \mathrm{nr} 4$ (139), http://www.berkovich-zametki.com/2011/ Zametki/ Nomer4/Chaban1.php (dostęp: grudzień 2014).

${ }^{25}$ J. Cieszyńska, Dwujęzyczność, dwukulturowość - przekleństwo czy bogactwo? O poszukiwaniu tożsamości Polaków w Austrii, Kraków 2006, s. 26.

${ }^{26}$ Ф. Горенштейн, Бердичев, s. 142. 
co wyrażało się walką z narodowymi korzeniami ${ }^{27}$. Ponadto w 1926 r. wprowadzono nowe prawo, dotyczące rodziny i małżeństwa, które miało ostatecznie zniszczyć ten rodzaj wspólnoty ${ }^{28}$. W takich okolicznościach, w pełni aprobowanych przez matkę, wychowywane są Rózia i Lusia. Nie wpaja się im zasad tradycji żydowskiej ani religii, w rezultacie stają się produktami systemu radzieckiego i podążają w stronę pełnej akulturacji i asymilacji. Ich tożsamość kulturowa jest całkowicie radziecka. Odcięły się od swojego historycznego narodu, od jego przeszłości. Nie posługują się jidysz, językiem swoich antenatów, choć zapewne go rozumieją. Ich językiem jest rosyjski z wpajaną nieustannie i swobodnie przez nie używaną, nowomową. Utożsamiając się z państwem radzieckim, przekształciły się w nową postać Żyda sowieckiego, wyrzekającego się korzeni, tradycji, pragnącego nie pamiętać o historii. Proces ten uwidacznia się jeszcze bardziej w trzecim pokoleniu. Ałła, córka Lusi, chce zmienić swoje „niepoprawnie” brzmiące patronimikum Pejsachowna na bardziej rosyjskie — Pietrowna. Wyrzeka się w ten sposób tego, co otrzymała w spadku po przodkach, a żydowsko-radziecka ,,pramatka" Rachela popiera jej zamysł.

Choć niejednokrotnie, zwłaszcza w czasie sprzeczek, Rachela obrzuca swoich bliskich wyzwiskami i przeklina, ale jednak zawsze, w sytuacji zagrożenia, staje w ich obronie. Ujmuje się nawet za buntowniczym, zuchwałym, nierzadko wobec niej niegrzecznym siostrzeńcem Wilją:

БРОНФЕНМАХЕР: Тише, Беба... Я спрашиваю, где отец этого парня? Он арестован как троцкист...

ЗЛОТА: (хватается за личо). Ой, вэй...

РАХИЛЬ: Тихо... Ты только, Злота, не пугайся... Виля, ты не бойся... Бронфенмахер, это наш ребенок... Это мой ребенок, такой же, как Рузя и Люся... Ты понял, Бронфенмахер... Дядя этого ребенка убит под Харьковом за советскую власть... А если ты еще скажешь слово, Бронфенмахер, так, как я держу руку, я тебе войду в лицо... ${ }^{29}$.

W trudnym momencie rodzina okazuje się ważniejsza niż ideologia. Rachela broni chłopca, którego ojciec został oskarżony o trockizm, w latach 30. XX wieku jeden z najcięższych zarzutów.

Pomimo dominującej w niej tożsamości radzieckiej, Rachela nierzadko postępuje zgodnie ze swoim żydowskim pochodzeniem, z tradycją przodków. Obie córki wydaje za mąż za Żydów. Wnuk Garik, robiąc na przekór babce i matce, chce wstąpić w związek małżeński z gojką Tiną, której ojcem może być Niemiec. Dla Racheli ta myśl jest w ogóle niedopuszczalna, robi wszystko, aby temu zapobiec. A jednak wybrankami obu wnuków zostały pochodzące ze wsi gojki. Nie satysfakcjonuje to Racheli, ale nie podejmuje ona już żadnych działań, mających na celu ingerencję w dokonany przez wnuków wybór. Akceptuje zmiany, jakie w życiu Żydów z dawnej strefy osiedlenia zainicjowała internacjonalistyczna polityka państwa radzieckiego.

Tożsamość Racheli jest hybrydowa, mozaikowa, bowiem tworzą ją elementy związane z przeszłością, które stanowią komponent żydowski, i aktywna część radziecka, na którą nadal oddziałuje otoczenie i która znajduje się w nieustannym procesie kształtowania. Żydowska część jej tożsamości, jej rodowód, jest reliktem, bowiem pozostały z niej tylko swarliwość, bezgraniczne macierzyńskie oddanie i zubożony jidysz. Rachela w zasadzie pragnie być kobietą radziecką. Broni swej identyfikacji sowieckiej, agre-

${ }^{27}$ M. Heller, A. Niekricz, Utopia u władzy. Historia Związu Sowieckiego, t. 1, London 1985, s. $140-141$.

${ }^{28}$ Tamże, t. 1, s. 143.

${ }^{29}$ Ф. Горенштейн, Бердичев, s. 26. 
sywnie reaguje na krytykę systemu, jak i na próby wykluczenia jej z tej społeczności. Poddaje się wpływom sowietyzacji świadomie, przyjmuje dobrowolnie nowy system jako coś lepszego od rzeczywistości przedrewolucyjnej. Pozycję w domu rodzinnym ma w pełni wyznaczoną i stabilną — jest jego panią, ale z czasem jej dominacja słabnie i nie dotyczy już następnych pokoleń. W przestrzeni publicznej nie zaprzecza swojej żydowskości i nie zamierza $\mathrm{z}$ niej rezygnować, godzi się z nią jak z czymś nieuniknionym. W swej samoidentyfikacji zintegrowała żydowskość i radzieckość, bowiem dla niej nie są one ze sobą sprzeczne, raczej stanowią naturalną jedność.

Starsza siostra Racheli, Złota, jest jej przeciwieństwem i wprowadza do ich wspólnego świata równowagę. Tożsamość Złoty wydaje się również hybrydowa, ale ze znaczną przewagą komponentu żydowskiego. Jej radzieckość jest mniej zauważalna. Jeszcze przed przewrotem październikowym brała udział $\mathrm{w}$ zebraniach eserowców i bolszewików, chcąc poznać głoszone przez nich idee. W nowym państwie radzieckim systematycznie uczęszcza na wybory. Podobnie jak w przypadku Racheli, osobowość Złoty poddawana jest ,pracy” ideologicznej. Z pewnością oddziałuje na nią propaganda radziecka, jednakże próba stworzenia „nowego człowieka” w tym wypadku nie przynosi efektu. Złota nie należy do partii, a jej język nie poddał się wpływom sowieckiej nowomowy. Dla Złoty istotna jest praca. Już w wieku ośmiu lat została uczennicą u krawca, a obecnie nielegalnie szyje dla majętnych kobiet Berdyczowa. Rachela nie pochwala tego, jej zdaniem siostra powinna być lojalna wobec kraju i pracować w państwowej spółdzielni. Rodzaj rzemiosła, którym zajmuje się Złota, stanowi istotny element jej żydowskości, bowiem w tej właśnie dziedzinie niegdyś mistrzami byli Żydzi. Uczestniczy w ważnych wydarzeniach z życia radzieckiego społeczeństwa, ale jej udział w głosowaniach oraz w uroczystościach z okazji Dnia Zwycięstwa odbywa się raczej na zasadzie nabytego nawyku, bowiem Złota nie zastanawia się nad sensem swych działań. Jednak nie angażuje się w bieżące sprawy kraju i zagranicy. W przeciwieństwie do Racheli pamięta o zdarzeniach sprzed przewrotu bolszewickiego oraz z okresu powstawania i umacniania się władzy radzieckiej. Odegrały one istotną rolę w historii społeczności sztetla: strajki pracowników (1915), grabieże i pogromy (1918), zmiany władzy w okresie wojny polsko-bolszewickiej. Czytała także książkę o pogromach berdyczowskich. Jest świadoma tragicznego losu Żydów. Fakt pełnego wpisania się Złoty w żydowską tożsamość narodową wydaje się potwierdzać anegdota (jedyna, jaką ta postać opowiada w toku dramatu):

ЗЛОТА: Я тоже знаю анекдот... Это еще до войны, когда Молотов встретился с Гитлер, так Молотов запел: „Страна моя...”, тогда Гитлер сзади его выставил ему язык и запел: „Москва моя...” (Смеется)

ПЫНЧИК: И все-таки не Гитлер в Москве, а мы в Берлине.

РАХИЛЬ: Злота, ты что, пьяная? Ди быст шикер? Что за анекдоты ты рассказываешь?

ЗЛОТА: Ну, я не могу... Она всегда хочет быть надо мной хозяйкой... У нас был сосед, так он очень смешно рассказывал этот анекдот.

МИЛЯ: А кто по национальности был этот сосед?

ЗЛОТА: Что? Он был парикмахер.

РАХИЛЬ: Она совсем глухая.

ЗЛОТА: Почему я глухая?

МИЛЯ: (смеется) Действительно, почему она глухая? Она очень правильно ответила на мой вопрос. Я ее спросил, какой он национальности, она говорит — парикмахер... ${ }^{30}$.

\footnotetext{
${ }^{30}$ Tamże, s. 54.
} 
Należy pamiętać, że pakt Ribbentrop-Mołotow wzbudził szczególne zaniepokojenie wśród ludności żydowskiej ${ }^{31}$. Anegdotę, która krążyła w środowisku Żydów berdyczowskich, Złota opowiada zaraz po wojnie (1946) wśród osób, których do końca nie zna. Antystalinowski wydźwięk, jaki niesie ze sobą owa humoreska, może grozić Łuckiej pociągnięciem do odpowiedzialności i ukaraniem jej kilkoma latami łagru. Wyjątkowo mocnego wydźwięku nabiera anegdota w kontekście pieśni śpiewanych na cześć Stalina przez innych gości i Rachelę. Sytuacja wskazuje, że Złota stanowi „mniejszość żydowską" w mieszkaniu, w stosunku do radzieckiej Racheli, jej córek i gości. Dlatego anegdota wywołuje oburzenie ze strony starszej siostry, w pełni utożsamiającej się z ideą bolszewicką. Złota przeciwstawia się dominującej idei, wyraża wierność wobec żydowskości, której korzenie tkwią w przedrewolucyjnym sztetlu. Aparat ideologiczny państwa sowieckiego okazał się wobec niej bezradny. Lojalność wobec żydowskości spowodowała, że jej osobowość jest harmonijna, spójna i trwała w upływającym czasie — światopogląd Złoty nie ulega zmianie na przestrzeni dramatu. Gorensztejn rysuje ją jako osobę spokojną, która podczas wykonywania swoich zajęć nuci i śpiewa. Jest wrażliwa, łatwo się wzrusza i często płacze. Współczuje na równi Żydom i ludziom innych narodowości, nie istnieją dla niej granice etniczne ani związane z nimi konflikty — ze wszystkimi chce żyć w zgodzie. Nie uczestniczy w skandalach ani w kłótniach i niejednokrotnie podejmuje próby uspokojenia zdenerwowanej siostry. Jej postawa wobec tego, co przynosi los, jest raczej pokorna. Nie walczy, nie stara się zmieniać rzeczywistości. Siostry często przekomarzają się, ale pomimo wielu nieprzyjemnych słów Złota jest oddana Racheli i stara się ją wspomagać dobrymi radami.

Złota, tak jak i siostra, posługuje się „okaleczonym” językiem rosyjskim. Nie odmienienia rzeczowników i buduje zdania niepoprawne gramatycznie. I w ciągu trzydziestu lat nie tylko nie doskonali swej ruszczyzny, ale także nie rozumie dokonujących się w niej zmian. Złota zna jidysz, i to raczej lepiej niż rosyjski. Używa wyrażenia „Ой, вэй з мир" równie często i w podobnych okolicznościach, jak jej siostra.

Istotnym czynnikiem budującym tożsamość żydowską bohaterki jest macierzyński stosunek do osieroconego siostrzeńca Wilji. Złota jest panną i nie ma własnych dzieci, a swoją niezrealizowaną matczyną miłość przelewa właśnie na tego chłopca. Jest w stosunku do niego wyrozumiała i łagodna, nie bacząc na wiele nieprzyjemnych słów, które kieruje pod jej adresem Wilja. Staje w jego obronie, gdy inni uskarżają się na jego nieposłuszeństwo oraz gdy z niepokojem patrzą w jego przyszłość — ona stale wierzy w tego krnąbrnego malca, a później wkraczającego w dorosłość młodzieńca. Taktuje go jak syna i mimo własnej trudnej sytuacji materialnej wspomaga go, kiedy on opuszcza już dom, wysyłając mu paczki z żywnością.

W tożsamości Złoty przeważa żydowskość i ma ona charakter naturalny. Ta świadomość przechowywana jest w pamięci, zawiera się w wykonywanej pracy oraz w posługiwaniu się jidysz. Jest starszą siostrą Racheli, dlatego też lepiej niż ona poznała i zapamiętała życie w strefie osiedlenia, w sztetlu. Wspomnienie o nim odnosi się głównie do wydarzeń tragicznych. Jej świat jest zamknięty, wyznaczają go granice Berdyczowa. Złota sprawia wrażenie osoby przeniesionej w czasie: wyrwanej ze sztetla i ulokowanej w systemie radzieckim. Naturalny charakter identyfikacji żydowskiej Złoty doskonale oddaje jej stwierdzenie, że nie uważa siebie za osobę religijną, ale wieprzowina ma dla niej nieprzyjemny zapach. Dostrzegalna prostota jej charakteru

${ }^{31}$ A. Lustiger, Czerwona księga. Stalin i Żydzi. Tragiczna historia Żydowskiego Komitetu Antyfaszystowskiego i radzieckich Żydów, tłum. A. Kaźmierczak, W. Leder, Warszawa 2004, s. 113. 
powoduje, że nie doświadcza ona świata intelektualnie i że otaczającą rzeczywistość odbiera przede wszystkim na poziomie emocjonalnym.

Obraz Sumiera wydaje się dopełniać prezentację tożsamości Złoty. Jest on, jeśli można tak powiedzieć, najbardziej żydowski z rodziny Łuckich, najbardziej utożsamia się ze swoim pochodzeniem. Przed wojną był właścicielem sklepu odzieżowego. Możliwe, że kontynuował kupiecką działalność swojego dziadka. Zdaniem Racheli, nie wyzbył się myślenia kapitalistycznego i nie jest usatysfakcjonowany tym, co otrzymał od nowego państwa. Sumierowi, tak jak i Złocie, wpojono w domu rodzinnym wartości związane z pracą, z prowadzeniem własnego interesu. Dlatego z nostalgią wspomina tamte czasy, gdy pracował tylko na własny rachunek. Obecnie kieruje spółdzielnią. W jego opinii każdy sam powinien zarabiać na swoje utrzymanie. Jest zwolennikiem pracy indywidualnej, a nie kolektywnej, która w Związku Radzieckim postrzegana była jako forma istotna i pożądana. Uważa, że mimo przemian polityczno-społecznych nadal istnieją nierówności ekonomiczne, podział na ludzi biednych i bogatych.

Samoidentyfikacja Sumiera w dużym stopniu zdeterminowana została przez historię. Opowiada on, że w roku 1918, gdy petlurowcy zajęli miasteczko, zmusili Żydów do rozkopywania masowych mogił berdyczowian, zabitych przez oprawców z Czeka. Miejscowa ludność chciała pochować rozstrzelanych z należytym dostojeństwem, a podczas ekshumacji złorzeczyła Żydom. Jednakże wśród ofiar byli również Żydzi, co starano się tuszować i mówiono, że w grobie pochowani są wszyscy oprócz Żydów. Sytuacja taka jak w przypadku Racheli i Mamatiuka, z jednym wyjątkiem: nie przeproszono Żydów, którzy rozkopywali mogiły, a Rachela usłyszała jednak słowa przeprosin. Nastawienie miejscowych wobec Żydów mogło wynikać z faktu, że wśród czekistów byli również Żydzi i to niejednokrotnie oni dokonywali egzekucji. W imię idei dopuszczali się morderstw nie tylko na swoich współobywatelach, ale również na członkach własnych rodzin. Yuri Slezkine zauważa, że w organach Czeka nie było zbyt wielu Żydów, choć propaganda Białych głosiła coś zupełnie odmiennego ${ }^{32}$. Mimo wszystko potraktowano Żydów jako współwinnych śmierci rozstrzelanych.

Sumier, tak jak i Złota, jest świadom tragicznej historii Żydów w Rosji. Pamięta, do jakiej grupy etnicznej przynależy i jaki los spotkał jego pobratymców. W związku z tym, gdy tylko pojawiła się sprzyjająca okoliczność — zademonstrował swoje przekonania: znieważył w Kijowie pomnik Bogdana Chmielnickiego i nazwał hetmana mordercą Żydów ${ }^{33}$. Napluł na pomnik ukradkiem, tak aby nikt nie zauważył, bowiem naruszał godność symbolu publicznego, posiadającego ważkie znaczenie narodowe dla Ukraińców. Manifestowanie swoich przekonań w przestrzeni publicznej mogło mieć katastrofalne skutki, dlatego Sumier zachował szczególną ostrożność. Podobny stosunek ma do systemu radzieckiego. Krytykuje go potajemnie, nie wprost, czasami trzeba się domyślać sensu jego wypowiedzi. Jego żydowskość widać w reakcjach na poglądy polityczne Racheli. Konstatuje ona, że Żydzi zasługują na pogromy dokonane przez Arabów, bowiem powinni być potulni i spokojni, a nie dokonywać najazdu na Egipt. Odpowiedź Sumiera, choć zawoalowana, zawiera jego opinię na ten temat:

${ }^{32}$ Y. Slezkine, Wiek Żydów, thum. S. Kowalski, Warszawa 2006, s. 197-198.

${ }_{33}$ Powstanie (lata 1648-1657) pod przywództwem Chmielnickiego, skierowane przeciwko polskiej magnaterii, doprowadziło do wybuchu antysemityzmu i pogromów ludności żydowskiej na terenach Rzeczypospolitej. Niektóre daty z tego okresu zapisały się w kalendarzu żydowskim jako dni żałoby. Kronikarze żydowscy podają, iż w czerwcu i lipcu 1648 roku zginęło około 100 tysięcy Żydów. Za: N. Jakowenko, Historia Ukrainy od czasów najdawniejszych do końca XVIII wieku, tłum. O. Hnatiuk, K. Kotyńska, Lublin 2000, s. 232. 
СУМЕР: Ой, Рухеле, да быст клиг зейве ман бобес циг... Ты умная, как моей бабушки коза... ${ }^{34}$.

Innym przykładem jest riposta na pytanie siostry, dotyczące jej medali. Oczywiście, Rachela oczekuje pochwał, jednakże brat nie uznaje tego za słuszne, co wyraża w żartobliwej frazie:

СУМЕР: Я скажу, что я уже забыл, ты никогда не будешь знать 35 .

Sumier jest wesołym kpiarzem o satyryczno-ironicznym, uszczypliwym, ale nie złośliwym języku. Żydowskość Łuckiego manifestuje się także poprzez jego charakter. Dużo się śmieje, wzbudza wesołość pośród otoczenia, a jego żarty są przywoływane nawet po jego śmierci. Rodzina jest dla Sumiera niezmiernie ważna. Jako starszy $\mathrm{z}$ rodzeństwa sprawuje nad siostrami opiekę, dba o nie i odnosi się do nich z ojcowską pobłażliwością. Jest częstym gościem w mieszkaniu Racheli. Niejednokrotnie z dezaprobatą wypowiada się o kłótniach, awanturach i hałasie, jakie panują w jej domu.

Bierną niezgodą na radziecką rzeczywistość jest także nieuczestniczenie w śpiewaniu podczas przyjęcia weselnego Rózi piosenek pochwalnych w języku jidysz na cześć rewolucji i Stalina. Sumier stwierdza, iż ich nie zna. Proponuje w zamian za to piosenkę z dawnego folkloru żydowskiego. Swoją niechęć do wyśpiewywania chóralnych peanów na cześć wodza tak uzasadnia:

СУМЕР: [...] я иудейского вероисповедания и не могу петь русская песня ${ }^{36}$.

Zaistniałą sytuację odniósł do czasów służby w armii carskiej, gdzie jako żołnierz wyznania mojżeszowego był zwolniony z wykonywania pieśni wojskowych.

Sumier jednakowo sprawnie posługuje się oboma językami — rosyjskim i jidysz. W jego wypowiedziach znacznie rzadziej występują typowe dla sióstr błędy stylistyczne i gramatyczne. Żydowska specyfika jego języka polega na odpowiedziach pytaniem na pytania (podobnie jest u Racheli):

РАХИЛЬ: (Сумеру) [...] Вот тут за стеной живет Бронфенмахер... Ты знаешь Бронфенмахера?

СУМЕР: А что, я не знаю Бронфенмахера из горкомхоза ${ }^{37}$

Wydaje się to cechą stylistyczną potocznego jidysz i wyrazem mentalności żydowskiej. Ten język, zapewne pierwotny dla Sumiera, używany bywa również nieświadomie, przez sen:

ЗЛОТА: Сумер, разденься, ляжь на тахта.

СУМЕР: (сквозь сон) А-а, чепе мех ныт... Не трогай меня... ${ }^{38}$.

W odróżnieniu od swoich sióstr, zrównoważony i pogodny Sumier nie stosuje żydowskiego, emocjonalnego wykrzyknienia „вэй з мир”. Wilja nazywa go berdyczowskim Wolterem. Analogia ta może dotyczyć bohatera opowiastki filozoficznej — Kandyda, który mimo przeciwności losu i nieszczęść, jakie go spotykają, jest pełen nadziei i optymizmu, że wszystko to prowadzi ku czemuś lepszemu. Podobnie bohater Gorensztejna, o wesołym usposobieniu i pozytywnym nastawieniu do życia, akceptujący wszystkie wydarzenia,

\footnotetext{
${ }^{34}$ Ф. Горенштейн, Бердичев, s. 90.

${ }^{35}$ Tamże, s. 46.

36 Tamże, s. 44.

37 Tamże, s. 22.

${ }^{38}$ Tamże, s. 84.
} 
z perspektywy czasu ciepło i z uśmiechem je wspomina. Sumier ma lekko ironiczny stosunek do świata zewnętrznego i do samego siebie. Nie jest to ironia złośliwa ani krzywdząca, wprost przeciwnie - postać wydaje się emanować ciepłem i troskliwością.

Najstarszy z żyjących Łuckich pamięta najwięcej z życia dawnego sztetla. Jest świadomy tego, że Żydzi utracili swoją prawdziwą tożsamość, że obecnie są wytworem ideologii sowieckiej. Zostali pozbawieni swojego świata i nie mają nadziei na jego odzyskanie. Jednak w walce o utrzymanie żydowskiej tożsamości nie traci pogody ducha. Strzeże swej indywidualności, mającej korzenie w wielowiekowej tradycji. Dostosował się do obowiązujących nowych praw, ale zachował swoje poglądy i swoje prawdziwe ,ja”. Jego tożsamość, wynikająca z rodowodu, jest monolityczna, samoświadoma, a jego wiedza o Żydach rosyjskich sięga poza teren Berdyczowa i daleko w przeszłość, aż do czasów hetmana Chmielnickiego.

Jedną z kluczowych postaci w konstrukcji dramatu wydaje się Wilja — ze względu na zmianę, jaka zaszła w jego procesie tożsamościowym. Poznajemy go jako nieposłusznego i buntowniczego nastolatka. Wobec ciotek jest zuchwały, niegrzeczny, szczególnie wobec Racheli. W stosunku do Złoty czasami bywa uprzejmy i wyrozumiały. Wcześnie został osierocony - matka zmarła podczas wojny. Na temat ojca niewiele wiadomo. Sąsiad, Isak Isajewicz Bronfenmacher, uważa go za trockistę. Wilja raz mówi, że nie wie, kto jest jego ojcem, innym razem — że zginął on na froncie. Złota wspomina szwagra jako profesora. Wszystkie rozrzucone w tekście dramatu informacje, dotyczące ojca, prowadzą ku stwierdzeniu, iż Wilja to alter ego pisarza. Opinię tę potwierdza Weksler, pisząc, że ta postać to literacki obraz samego Gorensztejna z okresu młodości ${ }^{39}$. Ojciec autora Berdyczowa był profesorem ekonomii i zginął w okresie Wielkiego Terroru. Oskarżenie o trockizm było wówczas częstym zarzutem. Nic więc dziwnego, że o ojcu Wilji jako o „wrogu narodu” w rodzinie Łuckich nie mówi się otwarcie, ale ucieka się do kłamstwa, tworząc własne historie. Potwierdzeniem są słowa Gorensztejna, który w wywiadzie przeprowadzonym przez Wekslera, powiedział:

Но я скрывал свою биографию. Это было очень опасно. Я имел фальшивую биографию ${ }^{40}$.

Trudne, sieroce dzieciństwo, nauka w państwowej szkole radzieckiej, której główną intencją było wychowanie „nowego człowieka”, powodują, że Wilja jako chłopiec, nie potrafi dokonać samookreślenia i wypiera się swojego żydostwa:

ВИЛЯ: Я хотел сказать, что я русский еврей, но „русский” я успел сказать, а „еврей” не успел, потому что меня срочно домой позвали...

ВИТЬКА: (хохоча) Его домой позвали...

ВИЛЯ: Нет, правда... Есть бухарские евреи в Средней Азии, есть грузинские - на Кавказе, а я русский... Хотя вообще-то я наполовину... Моя мать из Польши... А отец тоже не совсем ясно кто... Я был в детдоме, так меня эти евреи взяли на воспитание... Я ведь на еврея не похож...

МАКЗАНИК: (проходя мимо с пустым ведром) Только все евреи похожи на тебя... ${ }^{41}$.

Nie wiadomo, w jaki sposób przebiega proces dorastania i kształtowania się identyfikacji żydowskiej Wilji. Gdy ponownie pojawia się w Berdyczowie w połowie lat

${ }^{39}$ Ю. Векслер, Молились и черту тоже

40 Tenże, Фридрих Горенштейн. Каково качество „Белого”. Интервью, Иерусалимский журнал 2008 nr 29, http://magazines.russ.ru/ier/2008/29/go25.html (dostęp: październik 2011).

${ }^{41}$ Ф. Горенштейн, Бердичев, s. 32. 
70. XX wieku, po piętnastu latach nieobecności, jako inteligent pochodzenia żydowskiego, jest osobą dobrze znaną w wąskich kręgach moskiewskich. Uformowana już tożsamość żydowska staje się otwarta i świadoma swej wartości, mówiąc inaczej: dorosły już Willi Gerbertowicz to świadomy Żyd:

ЗЛОТА: Он устал. Иди спать, Виля... Сделать тебе на утро котлеты из куриного

бейлека?

РАХИЛЬ: Разве он знает, что такое бейлек?

ВИЛЯ: Знаю. Я ведь еврей. Бейлек - это белое мясо курицы ${ }^{42}$.

Posługuje się czystym, klasycznym rosyjskim, ale zna również jidysz. Posiada jasno opracowany program odnowy samoświadomości żydowskiej, dostrzega problemy tożsamościowe członków tej społeczności i ich lęki.

W swym rozumieniu znaczenia Berdyczowa jako źródła tożsamości jego mieszkańców, a także swojego własnego rodowodu, sięga początków historii miasteczka w XVI wieku. Wskazuje na zmiany przynależności państwowej oraz na znaczną liczbę mieszkańców żydowskich w końcu XIX wieku. W jego metaforycznej interpretacji Berdyczów to szpetna chatka, zbudowana przez diasporę żydowską z płyt świątynnych, miejsce, gdzie naród wybrany może się schronić i przetrwać. W ten sposób koncepcja Wilji nawiązuje do wielowiekowej historii diaspory, mającej swe źródła w okresie niewoli babilońskiej (VI w. p.n.e.), obejmującej swym zasięgiem tereny królestwa Judy. Żydzi byli kilkakrotnie zmuszani do opuszczania nowych miejsc osiedlenia, także w Europie. Z uwagi na tradycyjne wartości duchowe, jakie wnieśli ze sobą żydowscy mieszkańcy na nowo zamieszkane tereny, Berdyczów nazywano „Jerozolimą Wołynia” (a w dramacie „stolicą żydowską"). To właśnie religia, obrządek i obyczaj składały się na owe płyty świątynne, z których zbudowano sztetl. Być może obecnie, stwierdza Wilja, Berdyczów, jak i świat diaspory, wydaje się zniszczony, brudny i pozbawiony jakichkolwiek wartości, ale gdy rozłoży się go na części, to okaże się, że w tym mieście przetrwało coś, co jest święte - przetrwały podwaliny narodu.

Teorię, którą przedstawił Wilja, ilustruje powojenna egzystencja Łuckich. Powracają $\mathrm{z}$ ewakuacji i frontów - w poczuciu rozbicia i poniesionych strat — do rodzinnego, znanego i bliskiego miasteczka. Z trudem, mozolnie budują własną, wspólną przestrzeń - dom. Gdy na teren ich mieszkania zamierza wkroczyć sąsiad (notabene również Żyd), bronią prywatnej przestrzeni przed intruzem. Budują ją ze zdekompletowanych mebli, które z czasem uzupełniają nowymi. Ich „szpetna berdyczowska chatka” to wspólne miejsce przetrwania dla osadzonej w tradycji Złoty i radzieckiej Racheli. Ta przestrzeń, w której dorasta Wilja — mieszkanie ciotek, powojenny Berdyczów — to praprzyczyna i źródło jego żydostwa — ona stanowi jego rodowód.

Tytułowy Berdyczów to symbol strefy osiedlenia. Wraz z procesem sowietyzacji dawny sztetl traci nieodwracalnie swą dominującą żydowską tożsamość. Siostry Łuckie zajęły mieszkanie w budynku wzniesionym $\mathrm{z}$ inicjatywy miejscowego bogacza doktora Szrencisa. Postać ta wzorowana jest na lekarzu żydowskim, Dawidzie Mojsiejewiczu Szerencisie ${ }^{43}$, dawnym właścicielu kilku budynków w mieście. W ciągu trzech dekad przedstawionych w utworze Berdyczów podlega powolnym lecz nieubłaganym zmianom, tracąc swe żydowskie rysy. Historia ulega zapomnieniu i zniszczeniu. Daw-

42 Tamże, s. 194-195.

43 Dawid Mojsiejewicz Szerencis (1862-1938) — berdyczowski doktor, zaangażowany w sprawy miasta. Jego małżonką była Anna Sawieliewna Witis — siostra Jekateriny Sawieliewny Witis, matki Wasilija Grossmana. 
ny cmentarz żydowski przekształcono w park imienia Tarasa Szewczenki ${ }^{44}$. Powstają nowoczesne budynki w stylu lat 50 . XX wieku, a te istniejące zmieniają swoje przeznaczenie. Definitywnym końcem epoki sztetla jest brutalne wysadzenie wieży ciśnień, mieszczącej się $\mathrm{w}$ centrum miasta ${ }^{45}$. Wydarzenie to Wilja porównuje do utraty nosa, czyli charakterystycznego wyrazu etnicznej przynależności. Berdyczów powoli musi wyrzec się swojej indywidualności — przestaje być domem, schronieniem, bezpiecznym miejscem przetrwania.

Na początku akcji dramatu, jeszcze jako nastolatek, Wilja wdaje się w kłótnie a to z Rachelą, a to ze Złotą, „obdarza” kuksańcem kogo popadnie. Ale w ostatniej scenie sztuki jawi się już jako uformowany człowiek, Żyd, wnosząc tam, gdzie się pojawia, zrozumienie i równowagę. Podobnie Złota - nie buduje murów wobec świata zewnętrznego, nie toczy sporów. Swary utrudniają zespolenie Żydów. Ten aspekt przejawia się także w zachowaniu Sumiera, który nie uczestniczy w żadnej sprzeczce, nie chce być również świadkiem awantur pomiędzy członkami rodziny. Wewnętrzne waśnie niszczą więzy, które winny ją spajać. Dlatego skandalistka Rachela jest postacią w pewnej mierze negatywną. Mieszka z siostrą Złotą, ale więcej je dzieli, niż łączy ${ }^{46}$. Mają różne charaktery, światopoglądy, codzienne prace, posiłki, zakupy wykonują oddzielnie. Sprawia to wrażenie, jakby w jednym mieszkaniu żyły dwie odrębne rodziny. A mimo to, jak słusznie zauważa Elina Wasiliewa, świat Łuckich próbuje ochronić swoją niezależność, jest zamknięty, nie dopuszcza nikogo obcego ${ }^{47}$. Rachela nie potrafi zaakceptować zięciów, mimo że obaj są Żydami. Różnice w wychowaniu, w budowaniu tożsamości w oparciu o wartości inne niż żydowskie, powoduje, że świat tej rodziny jest nietrwały i pomimo starań wspólnota rodziny Łuckich jest słaba, a ich „świat trzeszczy w szwach". Odzwierciedla to scena rozpruwania szwów na odzieży Racheli. Najpierw w przypływie złości dokonuje tego córka, Rózia, następnie wnuk Garik. Za każdym razem „,naderwany” świat udaje się odbudować. Rozerwanie wewnętrznych więzi rodzinnych, doprowadzające do konfliktów międzypokoleniowych, jest efektem braku jednolitej tożsamości i trwałych, silnych korzeni. Jest konsekwencją upadku sztetla i jego wartości.

W okresie powojennym azylem dla obywateli radzieckich pochodzenia żydowskiego są ich domostwa. Poza ich murami są innymi, odszczepieńcami. Nie posiadają wspólnoty, do której mogliby przynależeć, na której pomoc mogą liczyć, wśród której mogą być sobą. Utracili wiarę w Boga, który mógłby służyć podporą. Dlatego, zdaniem Wasiliewej, większość $\mathrm{z}$ nich wybiera ucieczkę $\mathrm{z}$ berdyczowskiego świata ${ }^{48}$. Lusia zamieszkuje w Żytomierzu, Marik w Leningradzie, a Garik w Mińsku. Do Moskwy wyjeżdżają Bronfenmacher i Wilja. Bronfenmacher przyłącza się do moskiewskiej inteligencji pochodzenia żydowskiego, zaczyna żyć tak, jak pozostali mieszkańcy

${ }^{44}$ Pierwsze pochówki na cmentarzu żydowskim datowane są na przełom wieków XVI i XVII, ostatnie - na koniec XVIII stulecia. Park imienia Tarasa Szewczenki powstał w latach 30. XX w. Do dnia dzisiejszego zachował się na nim nagrobek cadyka Libera Elizera; А. П. Горобчук, Бердичів. Історія міста від заснування до сьогодення (історико-краєзнавчий нарис), Житомир, http://my.berdychiv.in.ua/history_berdychiv\#top11 (dostęp: styczeń 2014).

${ }^{45}$ Wieża ciśnień została wzniesiona w 1898 r., a zburzona w 1973.

${ }^{46}$ И. Ковальска-Пашт, Самосознание советских евреев в художественной интерпретации Фридриха Горенштейна. „Бердичев. Драма в трёх действиях, восьми картинах и 92 скандалах", Politeja 2013 nr 4 (26), s. 577-578.

47 Э. Васильева, Художественный мир

${ }^{48}$ Tamże. 
stolicy: modnie i nowocześnie, a skandale Racheli wzbudzają w nim niesmak, mimo że niegdyś brał w nich udział, ba, nierzadko był ich inicjatorem.

Rezygnację z żydostwa i przemianę w obywatela radzieckiego można porównać do wyjścia ludu Izraela $\mathrm{z}$ niewoli egipskiej. To historyczne wydarzenie stanowiło punkt pomiędzy tym, co odrzucono, a tym, co przyjęto za nowe ${ }^{49}$. Analogicznie w Związku Radzieckim dokonał się exodus ludu wybranego, zmierzającego $\mathrm{z}$ powrotem w kierunku ,niewoli”, drogą przeobrażania się w homo sovieticusa, w lud bez przeszłości i korzeni. Żydzi, poddając się procesowi asymilacji, zrobili krok wstecz, stając się niewolnikami systemu. Zrezygnowali ze swojego rodowodu.

Aleksandr Mielichow, interpretując poglądy Wilji, stwierdza, że jemu - jako człowiekowi wykształconemu, odnoszącemu sukcesy — potrzebna jest więź ze swoim prymitywnym narodem ${ }^{50}$. Gorensztejn pragnął takiej więzi, ale chciał być również wolny wewnętrznie. Jak pisze w pamflecie Do towarzysza Macy - literaturoznawcy i czlowieka, a także jego potomków ${ }^{51}$, po przybyciu do stolicy oczekiwał wsparcia, między innymi ze strony osób pochodzenia żydowskiego. Ale większość z nich głównie mu szkodziła, tylko Rosjanie okazali się otwarci i pomocni. Autor, decydując się na emigrację, wybrał Berlin Zachodni. Tu mógł być niezależny. Uważał, że w Izraelu nie zostałby zaakceptowany ani nie byłby wolny. Ale nie wyrzekł się swojego pochodzenia, związanego $z$ dawną strefą osiedlenia.

W związku z istotnym dla koncepcji Wilji postrzeganiem Berdyczowa i całej strefy osiedlenia, istotne wydaje się pytanie, dlaczego po tylu latach nieobecności przyjeżdża do dawnego sztetla? Wilja swą tożsamość żydowską kieruje w drodze rozwoju intelektualnego, w przeciwieństwie do Złoty lub Sumiera, których samoidentyfikacja jest naturalna, nabyta w procesie rozwoju jednostki. Wilja nie poznał tradycyjnego sposobu życia Żydów. Dlatego przyjazd do Berdyczowa może wynikać z uświadamianej, wewnętrznej potrzeby kontaktu z tradycją, być swego rodzaju pielgrzymką do miejsca świętego „Jerozolimy Wołynia”, ale także do miejsca pochodzenia jego i jego przodków. Sowiecki Berdyczów można interpretować jako zburzoną świątynię, której nieatrakcyjne już ruiny opuścili wierni, zapominając o życzeniu wyrażanym zarówno przez ich przodków, jak i przez nich samych, w każde święto Pesach: „W przyszłym roku w Jerozolimie”. Wilja tworzy w swojej teorii wizję wspólnoty wyobrażonej, na bazie której konstruuje się naród $^{52}$. Członkowie takiej wspólnoty, mimo że nie wszyscy się znają, powinni czuć się związani poprzez kulturę, tradycję, język i wspólną historię. Na tej zasadzie działały wspólnoty żydowskie w sztetlach. Wskazówki Wilji wydają się nieskomplikowane, ale zburzenie muru, który budowano setki lat, i odbudowanie więzi wewnętrznych jest procesem długotrwałym. Naród pojmowany jest tu w znaczeniu przenośnym, emocjonalnym i intelektualnym, jako grupa, którą spajają wspólne wartości.

Przodkowie, ich osobiste losy, wplecione w wielką narrację historyczną, prowincjonalne żydowskie miasteczko o jakże ludzkim obliczu, z jego tradycją, mieszkańcami

${ }^{49}$ Rabin S. Ph. De Vries Mzn., Obrzędy i symbole Żydów, tłum. A. Borowski, Kraków 2006, s. 171

${ }_{50}$ А. Мелихов, Уродливая хижина, Зарубежные записки $2008 \mathrm{nr}$ 16, http://magazines. russ.ru/zz/2008/16/me17-pr.html (dostęp: październik 2014).

${ }^{51}$ Ф. Горенштейн, Товарищу Маџа - литературоведу и человеку, а также его потомкам. Пемфлет-диссертация с мемуарными этюдами и личными размылилениями [Dо towarzysza Macy — literaturoznawcy i człowieka, a także jego potomków. Pamflet-dysertacja ze studiami pamiętnikarskimi i osobistymi rozmyślaniami], Зеркало загадок $1997 \mathrm{nr} 5$.

${ }^{52} \mathrm{~B}$. Anderson, Wspólnoty wyobrażone. Rozważania o źródlach i rozprzestrzenianiu się nacjonalizmu, tłum. S. Amsterdamski, Kraków 1997, s. 19-21. 
oraz ich codziennymi troskami to dla Fridricha Gorensztejna i świadectwo pochodzenia, i niewyczerpane źródło tożsamości. Choć w ruinie, jest ono przedmiotem kultu, swoistym ,wzgórzem świątynnym”.

\section{LITERATURA}

B. Anderson, Wspólnoty wyobrażone. Rozważania o źródłach i rozprzestrzenianiu się nacjonali$z m u$, tłum. S. Amsterdamski, Kraków 1997;

E. Baldwin, B. Longhurst, S. McCracken, M. Ogborn, G. Smith, Wstęp do kulturoznawstwa, tłum. M. Kaczyński, J. Łoziński, T. Rosiński, Poznań 2007;

J. Cieszyńska, Dwujęzyczność, dwukulturowość - przekleństwo czy bogactwo? O poszukiwaniu tożsamości Polaków w Austrii, Kraków 2006;

М. Чабан, Идиш в Одессе - 4. Ой, не надо мне сказать!, Заметки по еврейской истории $2011 \mathrm{nr}$ 4(139), http://www.berkovich-zametki.com/2011/Zametki/Nomer4/Chaban1.php (dostęp: grudzień 2014);

M. Głowiński, Nowomowa po polsku, Warszawa 1990;

Ф. Горенштейн, Бердичев, Москва 2007;

—, Как я был шпионом ЦРУ?, Зеркало Загадок $2000 \mathrm{nr}$ 9, s. 26-39;

А. П. Горобчук, Бердичів. Історія міста від заснування до сьогодення (історикокраєзнавчий нарис), Житомир, http://my.berdychiv.in.ua/history_berdychiv\#top11 (dostęp: styczeń 2014);

M. Heller, A. Niekricz, Utopia u władzy. Historia Związu Sowieckiego, t. 1, tłum. A. Mietkowski, London 1985;

—, Utopia u władzy. Historia Związu Sowieckiego, t. 2, tłum. A. Mietkowski, Londyn 1982;

N. Jakowenko, Historia Ukrainy od czasów najdawniejszych do końca XVIII wieku, thum. O. Hnatiuk, K. Kotyńska, Lublin 2000;

И. Ковальска-Пашт, Самосознание советских евреев в художественной интерпретации Фридриха Горенштейна. „Бердичев. Драма в трёх действиях, восьми картинах и 92 скандалах”, Politeja 2013 nr 4 (26), s. 573-586;

A. Lustiger, Czerwona księga. Stalin i Żydzi. Tragiczna historia Żydowskiego Komitetu Antyfaszystowskiego i radzieckich Żydów, tłum. E. Kaźmierczak, W. Leder, Warszawa 2004;

Ш. Маркиш, Плач о мастере, Вести 2008, http://www.sem40.ru/famous2/m1539.shtml (dostęp: październik 2014);

А. Мелихов, Уродливая хижина, Зарубежные записки $2008 \mathrm{nr}$ 16, http://magazines. russ.ru/zz/ 2008/16/me17-pr.html (dostęp: październik 2014);

Г. Никифорович, Фридрих Горенштейн: писатель и читатели, Иерусалимский журнал 2012 nr 41, http://magazines.russ.ru/ier/2012/41/g20-pr.html (dostęp: styczeń 2015);

М. Полянская, Берлинские записки о Фридрихе Горенштейне, Санкт-Петербург 2011;

Rabin S. Ph. De VriesMzn., Obrzędy i symbole Żydów, tłum. A. Borowski, Kraków 2006;

А. Синявский, Основы советской иивилизации, Москва 2001;

Y. Slezkine, Wiek Żydów, tłum. S. Kowalski, Warszawa 2006;

В. Шубинский, Мессианский вирус. Фридрих Горенштейн, Россия и еврейство: попытка введения в тему, http://www.narodknigi.ru/journals/38/messianskiy_virus/ (dostęp: maj 2013);

Э. Васильева, Художественный мир драмы Фридриха Горенштейна „Бердичев”, Семь искусств $2014 \mathrm{nr}$ 1, http://7iskusstv.com/2014/Nomer1/Vasiljeva1.php (dostęp: październik 2014);

Ю. Векслер, Фридрих Горенштейн. Каково качество „Белого”. Интервью, Иерусалимский журнал $2008 \mathrm{nr}$ 29, http://magazines.russ.ru/ier/2008/29/go25.html (dostęp: październik 2011);

-, „Меня будут признавать сквозь зубы”, http://www.svoboda.org/content/transcript/24350362. html (dostęp: lipiec 2013);

-, „Молились и черту тоже”, Независимая газета 2012, http://www.ng.ru/ ng_exlibris/2012-03-22/4_gorenstein.html (dostęp: styczeń 2014). 


\section{JEWISH LINEAGES IN THE LITERARY INTERPRETATION OF FRIDRIKH GO- RENSHTEIN: BERDYCHIV}

The focus of the article is on the drama Berdychiv by a "third wave" Russian Jewish emigrantFridrikh Gorenshtein. The author derives his Russian-Jewish ethno-cultural origin from one of the former Pale of Settlement's shtetls-Berdychiv. A literary image of Soviet Jewish identity built on the basis of the fictional Lucki family is presented in the article. The identity of some characters (Sumer, Zlota) is determined by the tradition and culture of the former shtetl bound up with Judaism and Yiddish, while others (Rachel) are shaped by the indoctrinating ideology of the Soviet Union that expresses itself, among others, in the cult of the "leader" and newspeak. The writer's alter ego, the orphan Vilya, constructs his identity on the ruins of the shtetl's old world, facing a new post-war reality. In Gorenshtein's understanding, Berdychiv was not just a little town with a distant Jewish past but, above all, a spiritual basis and a symbol, a sacred place for Soviet Jews aware of their origin.

KEYWORDS: Fridrikh Gorenshtein (Friedrich Naumovich Gorenstein); Judeo-Slavica; RussianJewish literature; Soviet Jewish identity.

\section{ЕВРЕЙСКИЕ РОДОСЛОВИЯ В ЛИТЕРАТУРНОЙ ИНТЕРПРЕТАЦИИ ФРИДРИХА ГОРЕНШТЕЙНА. БЕРДИЧЕВ}

Основой статьи является пьеса Бердичев авторства эмигранта „третьей волны” - Фридриха Горенштейна. Писатель свое еврейско-русское, этнично-культурное родословие выводит со старого штетла черты оседлости - Бердичева. В статье проанализировано литературный образ идентификации советских евреев на примере семьи Луцких. Идентификацю некоторых персонажей (Сумер, Злота) детерминировала традиция и культура старого штетла, связаная с иудаизмом и с языком идыш, а других (Рахиль) - индоктринованная идеология советского государства, которая проявляясь - между прочем - в культе „вождя” и новоязе. На руинах старого мира штетла и новой послевоенной реальности, создавал свою еврейскую идентификацию сирота, Виля, alter ego писателя. В его понимании Бердичев это не только местечко с дальней еврейской историей, это прежде всего фундамент, и одновременно символ, святынное место для советских евреев осознающих свое происхождение.

КЛЮЧЕВЫЕ СЛОВА: Фридрих Горенштейн; русско-еврейские исследования; идентификация. 